\title{
Factors Influencing Sustainability Among Food Manufacturers in Kenya
}

\author{
Mwaura Anne $^{1}$, Letting Nicholas ${ }^{2}$, Ithinji Gicuru ${ }^{3}$, Orwa Bula ${ }^{4}$ \\ ${ }^{1}$ Department of Business Administration, Dedan Kimathi University of Technology, Nyeri, Kenya \\ ${ }^{2}$ School of Management and Leadership, Management University of Africa, Nairobi, Kenya \\ ${ }^{3}$ Department of Accounting and Finance, Dedan Kimathi University of Technology, Nyeri, Kenya \\ ${ }^{4}$ Department of Business and Economics, Kenyatta University, Nairobi, Kenya \\ Email address: \\ annewanjiku06@yahoo.com (M. Anne),nletting@mua.ac.ke (L. Nicholas), igicuru@yahoo.com (I. Gicuru), bula.oh@yahoo.com (O. Bula)
}

\section{To cite this article:}

Mwaura Anne, Letting Nicholas, Ithinji Gicuru, Orwa Bula. Factors Influencing Sustainability Among Food Manufacturers in Kenya. International Journal of Sustainability Management and Information Technologies. Vol. 3, No. 1, 2017, pp. 1-9.

doi: 10.11648/j.ijsmit.20170301.11

Received: January 25, 2017; Accepted: February 13, 2017; Published: March 1, 2017

\begin{abstract}
As economic growth increases the level of energy and material utilization has also increased. Green Supply Chain Management (GSCM) has thus developed as a deliberate environmental approach which has been accepted by progressive organizations as a means to enhance sustainability in various countries. The Kenyan manufacturing sector has remained to be an important contributor to the Kenyan economy. Unfortunately, increase in Kenya's manufacturing activities has been related to the increased utilization of plastic bags as these are regularly used to package manufactured goods and groceries. Consequently, the Kenya Association of Manufacturers should be encouraged to adopt GSCM practices that minimize pollution and encourage environmental sustainability. This research aims to examine the factors that influence the adoption of green supply chain practices among food manufacturing firms in Kenya. To fully understand this issue the research investigates the various factors that drive sustainability and then examines the GSCM practices adopted by the various food manufacturers in Kenya. This study will assist different parties involved in the manufacturing sector to understand the role of GSCM drivers as they influence the adoption of GSCM practices. The study was conducted among the food manufacturing firms that are listed in the Kenya Association of Manufacturers directory. A cross- sectional survey was conducted on a sample size of 130 companies. The response rate was $73.8 \%$. Primary data was collected through questionnaires. Factor analysis was used examine the construct validity while multivariate liner regression was employed to test criterion validity. The results of this study indicate that government and industrial regulations should be combined with various organizational capabilities such as employee awareness so as to enhance sustainability in the country. Manufacturing firms in the country should also be encouraged to have clear environmental strategies and embrace environmental reporting to the public. This will enable the various firms to be more engaged in sustainability. Both external and internal pressures are thus important factors that influence the adoption of GSCM practices by food manufacturing firms in Kenya.
\end{abstract}

Keywords: Green Supply Chain, Sustainability, Stimulators, Food Manufacturing Firms, Kenya

\section{Introduction}

As economic growth increases the level of energy and material utilization has also increased. This has further caused resource depletion problems and environmental issues. Environment and climate changes have become a delicate issue and are receiving more attention now than before (Intergovernmental Panel on Climate Change, 2007). The greater part of these environmental problems are considered to originate from business organizations. Consequently, businesses have more obligations in carrying out their business activities as these should result in minimum environmental damage. Thus, business organizations have begun to realize the need to be environmentally conscious as they increasingly face competitive, regulatory, and community pressures to balance economic and environmental performance. Today, most associations are practicing environmental safety in their different activities as a concern 
towards environmental sustainability. Thus, Green Supply Chain Management (GSCM) has developed as a deliberate environmental approach which has been accepted by progressive organizations.

Green supply chain can be defined as the integration of environmental concerns into the inter-organizational practices of Supply chain management (SCM) (Sarkis, Zhu \& Lai, 2011). Srivastava, (2007) and Zhu et al., (2008) have portrayed green supply chain issues as important qualities and that businesses should compel their suppliers to adopt them so as to improve environmental performance. Green supply chain practices include adoption of green purchasing, green manufacturing, green distribution and adopting reverse logistics. These green practices enable a firm to reduce waste, assess suppliers on their environmental performance, develop more environment friendly products and reduce carbon emission. A GSCM driver is that which approves and applies green practices and green image in manufacturing industries so as to minimize pollution. An enabler therefore drives green supply chain management (GSCM) for adoption of green practices in manufacturing industries. Several studies on GSCM have determined a broad range of factors to develop environmental management initiatives and practices to its supply chain. GSCM practices can be motivated by firm's stakeholders' requests or induced by a company's need to have full compliance with environmental regulations, or even promoted by the firm's internal strategic motivations which are related to the opportunity to gain a competitive advantage in the market.

\subsection{Kenya's Food Manufacturing Sector}

The Kenyan manufacturing sector has remained to be an important contributor to the Kenyan economy. Increase in Kenya's manufacturing activities has been related to the increased utilization of plastic bags as these are regularly used to package manufactured goods and groceries. Not only are plastic bags a source of aesthetic pollution but they are also a threat to the biodiversity of the country. Even though the ban enforcement on the manufacture, importation and distribution of plastic carrier bags with gauges of less than 30 microns by both National Environmental Management Authority (NEMA) and the Kenya Bureau of Standards (KEBS) has helped lessen the use of flimsy plastic bags, it has done little to encourage the use of the more readily biodegradable paper bags or conventional bags (Businge et al., 2011). The manufacturing sector should, under the sponsorship of its umbrella Kenya Association of Manufacturers (KAM), be encouraged to adopt GSCM practices that minimize pollution and encourage environmental sustainability. There is therefore need for the manufacturing sector to implement strategies that will reduce the environmental impact of the goods that they offer.

The food manufacturing sector alone accounts for 70 percent of the industrial sector's contribution to GDP (Kenya National Bureau of Standards, KNBS, 2012). The sector is chiefly agro-processing, with the manufacture of food, tobacco, beverages and textile accounting for over 34 per cent of total sectoral value added (KIPPRA, 2013). This is in contrast to newly industrialized countries where their food manufacturing sector constitutes only a small share. Kenya's manufacturing sector suffers from limited value addition and diversification, high cost of inputs and low competitiveness and yet this sector has a high potential in employment creation and poverty alleviation in the nation (Bigsten et al., 2010). Recently there has been a shift towards export oriented manufacturing as the main thrust of Kenya's industrial policy seeing that the country aims to increase the share of products in the regional market from $7 \%$ to $15 \%$ and develop niche products for existing and new markets (KIPPRA, 2013).

\subsection{Problem Statement}

Many global corporations have adopted green practices to attain sustainability. According to Zhu, Sarkis \& Lai (2008) pressures to implement Green Supply Chain (GSCM) practices do not only come from governments but also from other third party organizations and consumers who are environmentally aware (Liu, Tang \& Xue 2012; Yang, 2013). Studies done in Canada, Japan, South Korea, Switzerland, and Taiwan indicate that companies that have gone green have employees who highly esteem them and often have a higher performance level than other companies (Zhu et al., 2008). Other studies in the US and Japan, indicate that customers may make purchasing decisions based on products that are manufactured by companies that have gone green while boycotting those products of companies that have not gone green (Dheeraj \&Vishal, 2012; Amemba, 2013 ).

Frequently researches on Green Supply Chain Management stimulators are criticized for their narrow perspectives and a lack of industrial relevance (Bhool \& Narwal, 2013). Though GSCM Practices have been implemented by various food manufacturers on an ad hoc basis, there is scarcity of literature as well as a lack of empirical evidence on how these practices have been influenced by GSCM stimulators in the Kenyan setup. There is also need to find an improved process for adoption and implementation of Green practices in food manufacturing industries to improve sustainability in Kenya. This study sought to fill this gap in contemporary research.

This research aims to examine the factors that influence the adoption of green supply chain practices among food manufacturing firms in Kenya. To fully understand this issue, the research investigates the various factors that drive sustainability and then examines the GSCM practices adopted by the various food manufacturers in Kenya. This study will assist different parties involved in food manufacturing to understand the role of GSCM stimulators as they influence the adoption of GSCM practices and sustainability in general.

This paper consists of five sections. The purpose and significance are given in the first section. In the next section the existing literature on sustainability, GSCM and theories are discussed in order to develop the research hypothesis. Section 3 will describe the methodology used in research. Section 4 tests the hypothesis and discusses the findings. Section 5 will give the concluding remarks. 


\section{Literature Review}

\subsection{Sustainability}

One of the most current issues which have significant world-wide importance is the global environmental sustainability. Currently, global natural sustainability faces certain risks which are largely caused by businesses and their inability to manage their resources efficiently. Some of the consequences, direct and indirect, are associated with increased waste disposal, water and air pollution, increased carbon footprint and threats to wildlife sustainability. In this respect, business supply-chain management is seen as one of the predominant factors in the management and preservation of the global environmental sustainability (IEA, 2009). The society needs sustainable behavior which ensures environmental balance.

Sustainability is the ability to continue. This is strategically important and it will shape the future of global business. Environmental issues are considered an integral part of the broad framework of sustainability. The World Commission on Economic Development describes a sustainable business as one "that meets the needs of the present without compromising the ability of future generations to meet their own needs" (WCED, 1987). Sustainability means that business activities should be able to protect the environment or minimize its impacts on the society and humanity and serve the society. Following the increased focus of research on environmental issues in supply chain management the emphasis is on environmental sustainability. From the supply chain perspective, this is referred to as green supply chain management (Zhu and Sarkis, 2004).

\subsection{Green supply Chain Management Practices}

Various studies have put forward various practices that can be used to achieve GSCM. Some researchers call them GSCM practices or activities. Liu et al. (2012), note that different organizations may adopt different GSCM practices depending on their operations and characteristics and the industrial sector (Huang, Tan \& Ding, 2012). Dheeraj \&Vishal (2012) examined four main practices of GSCM: green purchasing, green manufacturing and materials management, green distribution and marketing and reverse logistics. Shang et al. (2010) in a study on electronics related manufacturing firms in Taiwan, identified six green supply chain management elements: green manufacturing and packaging, environmental participation, green marketing, green stock, green suppliers, and green eco-design. Ninlawan et al. (2010) on the other hand considered green procurement, green manufacturing, green distribution, and reverse logistics in a study done on computer parts manufacturers. Similarly, Amemba et al. (2013) discussed green procurement, green manufacturing, green operations, reverse logistics and waste management as the major elements of GSCM. Some researchers have gone on to discuss single aspects of GSCM practices. For instance, Baines, Brown, Benedettini, \& Ball (2012), examined the green production aspect while Lagat (2013) looked at the aspect of green purchasing. The common GSCM practices in the above studies are green purchasing, green manufacturing, green distribution/marketing and reverse logistics. These are the parameters that have been adopted in this study.

\subsection{Theories}

\subsubsection{Institutional Theory}

The main theory used to explain the factors that influence the adoption of GSCM practices is the Institutional theory. The institutional theory (DiMaggio \& Powell, 1983) posits that organizations respond to influence from the society and governments so as to gain legitimacy. In seeking legitimacy institutions will adopt those characteristics of the organizations that they consider to be more successful. Institutional theory may explain how external pressures promote GSCM practices. However, there are still some remaining questions. Clemens \& Douglas (2006), indicate that both external drivers and internal resources drive environmental management practices but it is unclear how external and internal factors interactively promote GSCM practices. Governmental regulations can be key drivers for enterprises to implement GSCM practices. When a firm complies with the set standards, legislations and societal norms then the likelihood of its strategic survival is enhanced. Some firms may choose to imitate other firms that have already adopted green supply chains in order to survive. Such a firm will be protected from any possible consequences of environmental and social misconduct such as, protests, campaigns and sanctions (Peters, Hofstetter \& Hoffmann, 2011).

\subsubsection{Resource Based Theory}

The Resource Based Theory (RBT) (Penrose, 1959), states that firms compete based on their resources and capabilities. Resources are both tangible and intangible and refer to assets, processes and knowledge that are within the control of a firm and enable it to acquire sustainable competitive advantage (Peteraf \& Barney, 2003). Every firm controls a heterogeneous bundle of resources that is rare, imitable and valuable. Operational capabilities built through greening of supply chains further supports the value, rarity, inimitability, and non-substitutability aspects of the RBT (Förstl, Reuter, Hartmann \& Blome, 2010). The values associated with greening the supply chain and the competitive advantages gained are not essentially found in the supplier management stages of the supply chain but they could even be larger in the customer stages with green marketing capabilities and resources (Shang et al., 2010).

According to the institutional theory, therefore, firms operate in certain ways so as to gain social legitimacy. Consequently, social obligations become the most stimulating factors if firms are to adopt certain practices such as GSCM. Institutional theory will thus be used in this study to explain the external stimulators such as government and industrial regulations. The RBV theory will be used to explain the internal stimulators such as employees' knowledge, firm attributes such as the environmental policy, technological 
attributes of a firm and their influence on a company towards adoption of GSCM practices. Using the institutional theory, this research will examine how firms respond to powerful pressures from the government and industrial regulators thus gaining social legitimacy.

According to the above theories, certain factors can be considered that stimulate GSCM practices and build a case for greening supply chains. From the external business environment, there are institutional pressures that further influence businesses and their supply chains to embrace better social and environmentally responsible practices. Zhu et al. (2013) and Varsei et al. (2014), identify that institutional stimulators would originate from government regulations, industrial self-regulation, monitoring organizations such as NGOs. Institutional investors and the media, Business publications and education, trade or employer associations, and formal processes of stakeholder engagement have also been found to encourage institutional pressures. Studies done in Canada and England show that normative pressures drive enterprises to be more environmentally aware. However, there is need to understand how organizations respond to environmental issues (Ball \& Craig, 2010). Studies done in Sweden found the role of ISO 14001 to be a key motivator for Swedish firms to engage in environmental supply management practices (Nawrocka et al., 2009). Liu et al. (2011) carried out a study in China to analyze the relationship between green supply chain management level (LGSCM) and the classified determinant factors. The results indicated that a company's environmental management capacities enhanced by frequent internal training of employees, tends to increase its participation in GSCM. According to Diabat and Govindan (2011) GSCM stimulators that influence the implementation of these practices are: Certification of suppliers' environmental management system; environmental collaboration with suppliers; collaboration between product designers and suppliers to reduce and eliminate product environmental impacts; government regulation and legislation; green design; ISO 14001 certification; integrating quality environmental management into planning and operation process; reducing energy consumption; reusing and recycling materials and packaging, environmental collaboration with customers; and reverse logistics. A study carried out by Chang, Kenzhekhanuly \& Park (2013) identified customers as a source of external pressure equivalent to that which comes from governments since customers have an increased awareness of environmental issues and this influences the behavior of companies positively towards the management of environmental issues. McFadden et al., (2009) indicate that management is the sole driver of adoption of GSCM practices. This finding was disputed by Yang (2013) who found that uncommitted leadership was a major hindrance to change initiatives. Top management support is especially useful for environmental practices such as GSCM. Sarkis (2009), further points out that top management has a significant ability to influence, support the actual formation and implementation of green initiatives across the organization and is thus necessary for any strategic program success.
The stimulators identified by these studies can be classified into both external and internal stimulators. The external factors are government regulations, industrial regulations and monitoring organizations such as NGO's. Internal factors are customers, employees, management, ISO 14001 certification and the integration of quality environmental management into planning and operation process. The institutional theory can also be used to explain why firms in different economic settings and in different sectors of the same economy have different adoption rates. Consequently, this research will seek to find out whether or not the above stimulators contributes to the adoption of GSCM practices in Kenya.

\subsection{Conceptual Framework}

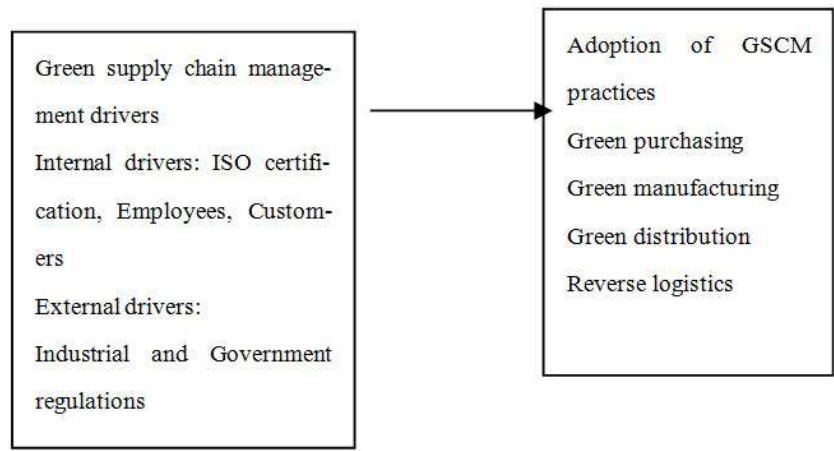

Figure 1. Conceptual Framework (Author, 2015).

Based on the extensive literature review on sustainability and the factors influencing the adoption of GSCM practices the above conceptual framework was developed. From the review of the empirical research the study hypothesized that:

$H_{0}$ : Green supply chain management stimulators have no statistically significant effect on the adoption of green supply chain practices among food manufacturing firms.

\section{Research Methodology}

This study in particular adopted a descriptive cross-sectional survey research design which can be used to collect data and make deductions about a population at a given time (Lavrakas, 2008). The food manufacturing companies that were included in this study consisted of those that were listed in the KAM directory 2014 and were strictly food processors or manufacturers. Thus of the one hundred and eighty one registered companies only one hundred and thirty companies were food manufacturers or processors and these made the target population. This study used a census survey approach for data collection. For populations of less than 1000 it is often necessary to conduct a census so as to achieve a high degree of statistical confidence in the survey results (Zhang, 2009).

GSCM stimulators were measured using the variables from literature. The variables are government regulations, industrial regulations, customers, employees, management, technological and firm attributes. Adoption of GSCM practices by firms was measured by the number of GSCM 
practices carried out by the various firms under investigation. This data was normalized in order to have the same range of values for each of the inputs and be able to compare and analyze the relationship between GSCM stimulators and adoption of GSCM practices.

The study used primary data which was collected using semi-structured questionnaire. The questionnaire administered contained Likert type questions as well as both open and closed ended questions so as to provide enough and accurate information in line with the objective of the study. They also gave the respondents a chance to give their views freely without any limitations. In order to test the reliability of the instruments, internal consistency techniques were applied using Cronbach's Alpha. Upon analysis of this data, the reliability coefficient for the factors was found to be 0.966 which showed a strong acceptable level of internal reliability (Bryman, 2008; Sekaran \& Bougie, 2010).

\section{Empirical Tests and Discussions}

\subsection{GSCM Drivers}

To establish the extent to which organizations were influenced by green supply chain management drivers, a five point Likert scale of 28 items was used (1-Strongly disagree, 2-disagree, 3-moderate, 4-Agree, 5-Strongly agree). The results illustrated that external stimulators that led to organizations' adoption of green supply chain supply practices.

According to the results, the main external stimulators that led to company's adoption of GSCM were; Government regulations (mean response 3.77 with a standard deviation of 1.06), competitors influence (mean response 3.66 and a standard deviation of 1.09), and employee influence through quality management and productivity improvement program (mean 3.63) with a standard deviation of 1.00. According to these results government regulation plays a very important role towards company's adoption of green supply chain practices. This is consistent with literature where Bhool \& Narwal (2013) indicate that government rules \& legislations are a major stimulator towards company's environmental management. This is because regulations increase the threats of penalties and thus this stimulator is most helpful for implementing GSCM in manufacturing industries.

GSCM practices were strongly influenced by government regulations $(\mathrm{r}=0.695, p=0.000)$ and industrial regulations $(\mathrm{r}=$ $0.636, p=0.000)$. GSCM practices were moderately influenced by competitor's adoption of GSCM ( $\mathrm{r}=0.494, p=0.000)$, customers influence $(0.481, p=0.000)$ and the maintenance of cleaner technologies which proved to be cost effective $(\mathrm{r}=.412$, $p=0.000)$. There was a weak relationship between implementation of cleaner technologies and the adoption of GSCM ( $\mathrm{r}=0.272, p=0.008)$.

The effects of firm attributes on the adoption of GSCM and firm competitiveness was further analyzed and the results showed that those companies that prepared and issued periodical and voluntary environmental reporting to the public and environmental bodies (mean response 3.60) with a standard deviation of 0.91 , were the ones that practiced green supply chain to the largest extent.

Using Pearson's moment correlation analysis, the extent to which firm attributes affect the adoption of GSCM practices was established. The results indicate that there was a strong correlation between all the firm attributes and the adoption of GSCM practices. GSCM practices were more strongly influenced by a firm that involved itself in championing the industry's environmental initiatives $(r=0.713, p=0.000)$ and by a firm that had set a budget for green research $(\mathrm{r}=0.691$, $p=0.000$ ). This shows that internal stimulators have a very significant and positive influence on whether or not a firm adopts GSCM practices.

\subsection{Factor Analysis on GSCM Drivers}

Factor loadings of all the indicators were above 0.5 . The KMO value for GSCM stimulators in this study was approximately 0.906 which is above the suggested minimum of 0.5 . This implies that the study sample was good for factor analysis procedure as recommended by Tabachnick and Fidell (2007). Bartlett's test of sphericity was significant $\left(\chi^{2}(36)=\right.$ $1977.253, p<.05)$. The diagonals of the anti-image correlation matrix were all over 0.5 , supporting the inclusion of each item in the factor analysis. It was also an affirmation that factor analysis was appropriate for the data. The indicators for GSCM stimulators constructs was found to explain $71.61 \%$ of the total variance in the data.

The results of factor analysis showed five factors after Varimax rotation. To identify the representation of these factors, it was important to consider the items that loaded on each of the five factors. During factor analysis, only absolute values of more than 0.50 were considered significant.

Nine items loaded on Factor 1 and can be categorized into having employees who are knowledgeable about green practices (.742) and when a company is clear about its environmental obligations. For a company to have employees who are knowledgeable about green practices it makes a conscious effort to hire green personnel (.573) and use employee suggestions to encourage green practices (.736). For a company to be clear on its environmental obligations it had clearly stated environmental objectives, included environmental issues in its mission and vision statements (.756), championed industrial environmental initiatives (.654) and was ready to spend to allow for green labeling of products (.636). This factor further suggests that for a firm to have a strategic environmental vision, it should be reflected by specific actions in the area of human resource management (training and employee involvement). It also ensures that a firm acquires a green image. This agrees with the findings of Murphy (2012) who prescribes that for management to be fully engaged in environmental improvement they need to have in place appropriate activities towards the reduction of environmental impact such as those mentioned above.

Six items loaded on Factor 2 and comprised of customers and competitor's perceptions. There was one factor that proved to be significant in both factors one and two. This was 
when a company advocates for industry environmental initiatives/ effort (.543). Customer's greatly influenced a firm's adoption of GSCM practices (.690). The other factors consisted of competitors and how they influenced the adoption of GSCM practices (.788). When competitors adopted quality management programs (.702), or pollution control programs (.615) they were deemed to be more competitive (.550). This suggests that both customers and competitors play a very significant role towards a firm's adoption of GSCM practices.

Factor 3 consisted of various organizational capabilities and employee awareness. When a firm was able to implement cleaner production technologies (.725), adopt quality management and productivity programs (.691) and adopt waste management programs (.614) all influenced by employees, was an important indicator that various company employees played a key role towards adoption of GSCM practices. Companies that prepared and issued periodical voluntary environmental reporting to the public and other environmental bodies (.568) proved to have adopted more of the GSCM practices than their counterparts that had not embraced voluntary reporting.

The fourth factor consisted of government and industrial regulations. Government regulations (.771) and industrial regulations (.722) both play a very important part for companies to adopt green practices. It also suggests that the government is the key determinant of green supply chain practices adoption in the manufacturing sector in Kenya (Kinoti, 2012).

The fifth factor consisted of 3 factors which can be classified as the effect of adopting GSCM practices on a firm. Implementation of cleaner production technology was perceived to enhance the adoption of GSCM practices (.775), improve the financial position of a company (.665) as well as increase the profit levels of the firm (.663). When firms adopt
GSCM practices they are able to realize significant additional profits. This finding concurs with that of Wamalwa (2014) who prescribes that when firms adopt sustainable supply chain management, they realize significant additional profits by acting within the triple sustainable issues of social, environmental and economic.

\subsection{Hypothesis Testing}

The study used stepwise regression analysis to investigate the association between the adoption of GSCM practices and the various stimulators which influence adoption by food manufacturing firms in Kenya. Stepwise regression is used as a semi-automated process of building a model by successively adding or removing variables based solely on the $t$-statistics of their estimated coefficients. The hypothesis to be tested was:

$H_{0}$ : Green supply chain management stimulators have no statistically significant effect on the adoption of green supply chain practices among food manufacturing firms.

The factors were categorized into two categories: external and internal stimulators. The regression model that was thus used to capture this relationship was presented in the following equation;

$\mathrm{Y}=\beta_{0}+\beta_{1} \mathrm{X}_{1}+\beta_{2} \mathrm{X}_{2}+\varepsilon$

Where $Y$ is adoption of GSCM

$\beta_{0}$ and $\beta_{1}$ are coefficients

$\mathrm{X}_{1}=$ external drivers

$\mathrm{X}_{2}=$ internal drivers

$\varepsilon=$ Error term

Results of the regression analysis are presented in Table 1 which illustrates the model fitness of the regression equation that was used to explain the relationship.

Table 1. Regression results of various factors and their influence on GSCM adoption.

\begin{tabular}{|c|c|c|c|c|c|c|}
\hline \multicolumn{7}{|c|}{ Coefficients $^{\mathrm{a}}$} \\
\hline \multirow{2}{*}{ Model } & & \multicolumn{2}{|c|}{ Unstandardized Coefficients } & \multirow{2}{*}{$\begin{array}{l}\text { Standardized Coefficients } \\
\text { Beta }\end{array}$} & \multirow[b]{2}{*}{$\mathbf{t}$} & \multirow{2}{*}{ Sig. } \\
\hline & & B & Std. Error & & & \\
\hline \multirow{2}{*}{1} & (Constant) & 1.038 & .218 & & 4.767 & .000 \\
\hline & External drivers & .715 & .061 & .793 & 11.726 & .000 \\
\hline \multirow{6}{*}{2} & (Constant) & .911 & .209 & & 4.359 & .000 \\
\hline & External drivers & .400 & .111 & .444 & 3.588 & .001 \\
\hline & Internal drivers & .354 & .107 & .408 & 3.304 & .001 \\
\hline & F- Statistics & & & & & 82.623 \\
\hline & $\mathrm{R}^{2}$ & & & & & 0.674 \\
\hline & Adjusted $\mathrm{R}^{2}$ & & & & & 0.666 \\
\hline
\end{tabular}

Dependent Variable: adoption of GSCM

During the stepwise regression both external and internal stimulators were picked out as significant. The equation for establishing the effect of the stimulators on adoption of GSCM practices when confined to the standardized coefficient, therefore was:

$$
\mathrm{Y}=1.038+0.444 \mathrm{X}_{1}+0.408 \mathrm{X}_{2}
$$

This model demonstrates that when all factors are held together the value of adoption would be 1.03. However, holding other factors constant a unit increase in the external stimulators would increase the adoption by $44.4 \%$ while a unit increase in the internal stimulators would increase the adoption by $40.8 \%$.

Table 2. Model Summary.

\begin{tabular}{lllll}
\hline \multicolumn{3}{l}{ Model Summary } & & \\
\hline Model & \multirow{2}{l}{ R } & R Square & $\begin{array}{l}\text { Adjusted R } \\
\text { Square }\end{array}$ & $\begin{array}{l}\text { Std. Error of the } \\
\text { Estimate }\end{array}$ \\
\hline 1 & $.793^{\mathrm{a}}$ & .629 & .625 & .41897 \\
2 & $.821^{\mathrm{b}}$ & .674 & .666 & .39547 \\
a. Predictors: (Constant), external drivers \\
b. Predictors: (Constant), external drivers, internal drivers \\
\hline
\end{tabular}


The model fitness found that $62.9 \%$ of adoption of GSCM practices is explained by the external stimulators $\left(\mathrm{R}^{2}=0.629\right.$, Adjusted $\left.\mathrm{R}^{2}=0.625\right)$. Model 2 shows that when a firm integrates internal stimulators in addition to the external stimulators the adoption of GSCM practices increases by $4.9 \%$ $\left(\mathrm{R}^{2}=0.674\right.$, Adjusted $\left.\mathrm{R}^{2}=0.66, p=.000\right)$.

The findings from this research thus indicate that the GSCM stimulators do have a significant and positive effect on the adoption of GSCM practices by food manufacturing firms in Kenya. It was also established that when a firm adopts certain internal attributes the adoption of GSCM practices was enhanced. The coefficient of internal stimulators had a t-statistic value of 3.304 with a $p$ value $<.005$ while that of external stimulators had a t-statistic value of 3.588 and a $p$ value $<.005$. It was thus established that the relationship between the various stimulators and the adoption of GSCM practices was thus strong.

Using the ANOVA table the study established the significance of the regression model. In model $1 F_{(1,81)}=$ 137.496, $p<.001$ shows a significant relationship between the external drivers and the adoption of GSCM practices. Model 2 shows that the influence of both external and internal drivers is also significant for $F_{(2,80)}=82.623$ and has a $p$ value $<.000$. The study used ANOVA to establish the significance of the regression model from which an $F$-significance value of $p<0.001$ was established. This shows that the regression model has a less than 0.001 chance of giving a wrong prediction.

\subsection{Discussion}

The result in this research indicated that, green supply chain management stimulators have a statistically significant effect on the relationship between green supply chain practices and firm competitiveness. The researcher therefore rejects the null hypothesis "Green supply chain management stimulators do not positively influence the adoption of GSCM practices" while $\mathrm{H}_{\mathrm{a}}$ is accepted that, "Green Supply Chain Management stimulators have a statistically significant and positive influence on the adoption of GSCM practices by food manufacturing firms in Kenya.

According to these results government regulations play a more important role than industrial regulations towards a company's adoption of green supply chain practices. These findings are in agreement with the findings of Zhu et al. (2008) and Varsei et al. (2014), who state that governments try to mitigate environmental issues by enacting tighter environmental regulatory legislations thus leading the way in greening the supply chains. These researchers indicate that the pressure on enterprises to adopt green supply chain management practices mainly comes from the government environmental regulations factors.

According to the results posted in this study, competitors are more influential than customers towards a company's adoption of green supply chain practices. This finding contradicts many other researchers who argue that customers are more influential than competitors (Simchi-Levi et al., 2008; Chopra \& Meindl, 2012; and Varsei et al, 2014). For instance, Chopra \& Meindl, (2012) indicate that customers have a larger effect on enterprises' adoption of green supply chain management practices than suppliers or customers. However this finding is similar to Chang et al. (2013) who found that customers do not influence companies to adopt GSCM practices.

Internal pressures consisted of technology, firm attributes such as the vision, mission statement as well as employee influence. Of these, employee influence and technology are more influential towards adoption of GSCM practices by a company. Both employees and technology are resources according to the resource base viewpoint, and firms need to ensure that they have the potential to implement GSCM in terms of cost, quality and culture (Varsei et al, 2014). Of the two, according to this study, employees are a greater strength than technology. This finding supports that found by Liu et al. (2012) who indicated that employees play a very significant role in the adoption of GSCM practices. It was also interesting to note that the firms which practiced GSCM to a larger extent also prepared and issued periodical and voluntary environmental reporting to the public and environmental bodies. This can be attributed to the fact that these organizations are more aware of the benefits of GSCM practices as revealed through an in-depth interview.

\section{Conclusion}

With increasing competition in today's global market, the various manufacturing firms within the Kenya have to look to the modern strategic ways to gain a competitive advantage. Green Supply Chain Management (GSCM) is a new innovative managerial tool that can be used as a strategic weapon to gain competitiveness and to promote a firm's $s$ environmental and financial performance simultaneously.

The results of this study indicate that government and industrial regulations should be combined with various organizational capabilities such as employee awareness so as to enhance sustainability in the country. Firms that prepared and issued periodical voluntary environmental reporting to the public and other environmental bodies were shown to have adopted more of the GSCM practices. In addition firms that incorporated a clear environmental strategy in their vision and mission statements were also proactively involved in their environmental commitments. Thus manufacturing firms in the country should be encouraged to have clear environmental strategies and embrace environmental reporting to the public. This will enable the various firms to be more engaged in sustainability. Both external and internal stimulators are thus important factors that influence the adoption of GSCM practices by food manufacturing firms in Kenya.

\section{References}

[1] Amemba, C. S. (2013). Green supply chain best practices in hospitality industry in Kenya. Global Journal of Commerce \& Management Perspective, Vol. 2 (3), 7-18. 
[2] Amemba, C. S., Nyaboke, P. G., Osoro, A. \& Mburu, N. (2013) Elements of green supply chain management. European Journal of Business and Management, Vol.5 (12), 51-61.

[3] Baines, T., Brown, S., Benedettini, O. \& Ball, P. (2012). Examining green production and its role within the competitive strategy of manufacturers. Journal of Industrial Engineering and Management, Vol 5 (1), 53-87.

[4] Ball, A. \& Craig, R. (2010). Using neo-institutionalism to advance social and environmental accounting. Critical Perspectives on Accounting, Vol. 21 (4), 283-293.

[5] Bhool, R. \& Narwal, M. S.(2013). An Analysis of Drivers Affecting the Implementation of Green Supply Chain Management for the Indian Manufacturing Industries. International Journal of Research in Engineering and Technology. Vol 2 (11), 242-254.

[6] Bigsten A., Kimuyu P. and Soderbom M. (2010), “The Manufacturing Sector", In: Christopher S. A., Paul, C. and Njuguna, S. N. (eds), Kenya: Policies for Prosperity. Oxford: Oxford University Press.

[7] Businge, M. S., Ondimu, K., Maina, I., Mutai, C. C., Ochola, S. O., Ali, A. A., Gichora, M., Gachimbi, L. N. \& Mocha, A. (2011). Kenya: State of the environment and outlook 2010. Supporting the delivery of Vision 2030. Nairobi: Progress Press co. Ltd, Malta.

[8] Bryman, A. (2008). Social research methods ( $3^{\text {rd }}$ ed.). Oxford: Oxford University Press.

[9] Chang, B., Kenzhekhanuly, Y. \& Park, B. (2013). A Study on Determinants of Green Supply Chain Management Practices. International Journal of Control and Automation, Vol 6 (3), 199-208.

[10] Clemens, B. \& Douglas, T. J. (2006). Does coercion drive firms to adopt 'voluntary' green initiatives? Relationships among coercion, superior firm resources, and voluntary green initiatives. Journal of Business Research, Vol. 59 (4), 483-491.

[11] Chopra, S. \& Meindl, P. (2012). Supply Chain Management;5 edition. Prentice Hall.

[12] Dheeraj, N. \& Vishal, N. (2012). An Overview of Green Supply Chain Management in India. Research Journal of Recent Sciences. Vol 1 (6), 77-82.

[13] Diabat, A. \& Govindan, K., (2011) “An Analysis of the Drivers Affecting the Implementation of Green Supply Chain Management", Resources, Conservation and Recycling. 55, 659-667.

[14] DiMaggio, P. J. \& Powell, W. W. (1983). The iron cage revisited. Institutional isomorphism and collective rationality in organizational fields. American Sociological Review Vol. 48 (2), 147-160.

[15] Förstl, K., Reuter, C., Hartmann, E., \& Blome, C. (2010). Managing supplier sustainability risks in a dynamically changing environment-Sustainable supplier management in the chemical industry. Journal of Purchasing and Supply Management.

[16] Huang, X., Tan, B. L. \& Ding X. (2012). Green Supply Chain Management Practices: A Sectoral Investigation into Manufacturing SMEs in China. International Conference on Economics, Business and Marketing Management.147-151 (2012) IACSIT Press, Singapore.
[17] IEA (2009). Design and operation of power systems with large amounts of wind power. Available at http://www.iea.org/Textbase/publications/free_new_Desc.asp.

[18] Intergovernmental Panel on Climate Change, 2007. "Summary for Policymakers". in: Martin L. Parry, Osvaldo F. Canziani, Jean P. Palutikof, Paul J. van der Linden and Clair E. Hanson (eds.), Climate Change 2007: Impacts, Adaptation and Vulnerability. Contribution of Working Group II to the Fourth Assessment Report of the Intergovernmental Panel on Climate Change. Cambridge: Cambridge University Press, pp. 7-22.

[19] Kinoti, M. W. (2012). Green marketing practices, corporate image, organizational characteristics and performance of ISO 9000 and 14000 certified organizations in Kenya. Unpublished $\mathrm{PhD}$ thesis of the University of Nairobi.

[20] KIPPRA. (2013). Kenya Economic Report: Creating an Enabling Environment for Stimulating Investment for Competitive and Sustainable Counties. Nairobi.

[21] Lagat, J. (2013). Factors affecting integration of green purchasing in procurement at Kenya Airways Limited. International Journal of Social Sciences and Entrepreneurship, 1 (7), 216-251.

[22] Lavrakas, P. J. (2008). Encyclopedia of survey research methods. (pp. 524-527). Thousand Oaks, CA: SAGE Publications.

[23] Liu, L., Tang, M. \& Xue, F. (2012), The impact of manufacturing firms' green supply chain management on competitive advantage, Advanced Materials Research, Vol. 472 3349-3354.

[24] Liu, X., Yang, J., Qu, S., Wang, L., Shishime, T., \& Bao, C. (2012). Sustainable Production: Practices and Determinant Factors of Green Supply Chain Management of Chinese Companies. Business Strategy and the Environment, Vol. (21), $1-16$.

[25] Liu, X., Yang, J., Qu, S., Wang, L., Shishime, T., \& Bao, C., (2011) "Sustainable Production: Practices.

[26] Liu, X., Yang, J., Qu, S., Wang, L., Shishime, T., \& Bao, C. (2012). Sustainable Production: Practices and Determinant Factors of Green Supply Chain Management of Chinese Companies. Business Strategy and the Environment, Vol. (21), 1-16.

[27] McFadden, K. A., Xiao, S., Zhou, C. \& Kowalewski, M. (2009) Quantitative evaluation of the biostratigraphic distribution of acanthomorphic acritarchs in the Ediacaran Doushantuo Formation in the Yangtze Gorges area. South China: Precambrian Research. Vol. 173, p. 170-190.

[28] Murphy, E. (2012). Key Success Factors for Achieving Green Supply Chain Performance; A study of UK ISO 14001 Certified Manufacturers. (PhD thesis, The University of Hull).

[29] Nawrocka, D., Brorson, T., \& Lindhqvist, T., (2009). "ISO 14001 in environmental supply chain practices", Journal of Cleaner Production, 17, 1435-1443.

[30] Ninlawan, C., Seksan P., Tossapol K. \& Pilada W. (2010). The implementation of green supply chain management practices in electronics industry. Proceedings of the International Multi Conference of Engineers and Computer Scientists, 17-19 March 2010 Hong Kong.

[31] Penrose, E. T. (1959). The Theory of the Growth of the Firm. New York: John Wiley. 
[32] Peteraf, M. \& Barney, J. (2003). Unraveling the Resource-Based Tangle. Managerial and Decision Economics, 2003, Vol. 24, 309-323.

[33] Peters, N., Hofstetter, J. \& Hoffmann, V. (2011). Institutional entrepreneurship capabilities for interorganizational sustainable supply chain strategies. The International Journal of Logistics Management, Vol. 22 (1), 52-86.

[34] Sarkis, J. (2009). Convincing industry that there is value in environmentally supply chains. Problems of Sustainable Development, Vol. 4 (1), 61-64.

[35] Sarkis, J., Zhu, Q. \& Lai, K. (2011). An organizational theoretic review of green supply chain management literature. International Journal of Production Economics, Vol 130 (1), $1-15$.

[36] Sekaran, U. \& Bougie, R. (2010). Research methods for business: A skill building approach (5th ed.). West Sussex, UK: John Wiley \& Sons Ltd.

[37] Shang, K. C., Lu, C. S., Li, S., (2010) "A taxonomy of green supply chain management capability among electronics-related manufacturing firms in Taiwan", Journal of Environmental Management, 91, 1218-1226.

[38] Simchi-Levi, D., Kaminsky, P. \& Simchi-Levi, E. (2008). Designing and managing the supply chain: concepts, strategies, and case studies. 3rd edition. New York.: Mc Graw Hill.

[39] Srivastava, S. K. (2007). Green supply-chain management: A state-of-the- art literature review. International Journal of Management Reviews, (9), 1, 53-80.

[40] Tabachnick, B., \& Fidell, L. (2007). Using Multivariate statistics. Boston: Pearson Education Inc.
[41] Varsei, M., Soosay, C., Fahimnia, B. \& Sarkis, J. (2014). Framing sustainability performance of supply chains with multidimensional indicators. Supply Chain Management: An International Journal, Vol. 19 (3), 242-257.

[42] Wamalwa, P. B. (2014). Sustainable Supply Chain Management as a Strategic Tool for Competitive Advantage in Tea Industry in Kenya. Journal of Management and Sustainability; Vol. 4, (3), 157-164.

[43] World Commission on Environment and Development, 1987. Our Common Future. Oxford: Oxford University Press.

[44] Yang, M. G. (2013, May). Developing a focal firm's sustainable supply chain framework: drivers, orientation, practices and performance outcomes. ( Doctoral dissertation, University of Toledo).

[45] Zhang, D. (2009, April 27). Advantages and Disadvantages of Census Surveys. Retrieved November 25, 2014, from Web surveys: http://survey.cvent.com.

[46] Zhu, Q. \& Sarkis, J. (2004). Relationships between operational practices and performance among early adopters of green supply chain management practices in Chinese manufacturing enterprises. Journal of Operations Management, Vol. 22 (3), 265-289.

[47] Zhu, Q., Sarkis, J. \& Lai, K. H. (2008). Confirmation of a measurement model for green supply chain management practices implementation. International Journal of Production Economics, Vol 111, 261-273.

[48] Zhu, Q., Sarkis, J., Cordeiro, J. J. \& Lai, K. H. (2008). Firm-level correlates of emergent green supply chain management practices in the Chinese context. Omega, 36 (4), $577-591$. 